\title{
Cancer an Ayurveda perspective
}

\section{Introduction}

Every culture, society or country, primitive or progressive, has tried to keep its inhabitants healthy and happy. In this pursuit they made observations, accumulated knowledge, and thus developed values, rules and guidelines that through ritualistic implementations became traditions. The older the culture, the greater the accumulated wealth of knowledge, exemplified by China, Egypt, India, Mesopotamia, Middle Eastern Countries and Europe. Most of this endowed traditional knowledge was passed on from generation to generation as folklore, with little written documentation, since paper has not yet been discovered. Some documentation can be found inscribed on stones, cave paintings etc. The earliest known documentation (estimated age about 5,000years) exists in India.

Some written on birch bark later documents are found written on bamboo and wooden strips. Most of the ancient Indian documentation is found in four books of knowledge, the Ved (Sanskrit words will be in Italics; Vedas in Western literature). Subsequent elaboration of specific disciplines or topics resulted in separate documents, Upvedas- Ayurveda could be considered as an Upveda. As advances, further observations, experimentation, concepts, principles and practices emerged, these were collected in the form of 'Samhitas', or compilations.

Two of the Vedas, Rig -Ved and Atharva-Ved deal with health related topics. Rig-Vedhas more information on surgical aspects and Atharva-Veddeals extensively with treatment and cure of diseases. A few citations from Atharva-Ved depict the use of plants to treat specific ailments:

1. Prushnaparni (Urariapicta) Blood purification, destroys fetus, bleeding piles (2-25-1-4)

2. Kusta (Saussurialappa) Skin diseases, epilepsy, loss of hair, head skin diseases, tumors, against excess of Vata-Kapha (5-4-1-10)

3. Apamarg (Achyranthusaspara) Mouth- teeth diseases (7-67-1-3); thirst, hunger (4-17-1-8,4-18-1-8)

4. Durva (Crataevanurvala) 100s uses, detoxification, longevity, tonics $(3-11-1-8)$

5. Guggulu (Commiphoramukul) inhalation of fumes cures tuberculosis(19-36-1-3), contact infections, inflamations(4-37-1-2)

One has to project into India's past to understand Ayurveda and its contributions. The original Sanskrit writings add subtle meanings that cannot easily be translated. Ayurved is made up of two words: Ayuhoo (Phonetic pronunciation) and Ved (knowledge). According Sanskrit grammar rules, when two words are united (Sandhi), the final word is changed, so Ayuhoo + Ved $=$ Ayurved $=$ Ayurveda in English . Ayu means living or life and also connotes moving and longevity (Ayus). Ayus also carries additional meanings namely body (Deh), living (Jivita), organs (Nityaga) and sense of continuum (Anubahdha, In Vedanta meaning of Anubahdha carries further understanding of such connectivity which has a topic, a reason, an authenticity and their relationships with each other. Hence Ayurveda collectively includes all these connotations, and becomes knowledge of life and in simple
Volume 7 Issue I - 2017

\section{Gaurang Joshi}

Atharva Multi Specialty Ayurveda Hospital and Cancer, India

Correspondence: Gaurang Joshi BAMS, MD, Director, Atharva Multi Specialty Ayurveda Hospital and Cancer, Research Center, Rajkot, India, Email drgaurang-joshi@yahoo.com

Received: July 28, 2016 | Published: January 09, 2017

terms mean longevity, the science of human health. Ayu was first cited in Rig-Ved.Ayurved has been elaborated on in Atharva-Ved. Though ancient culture proliferated on fertile land on the banks of several rivers, the ancient seers had visualized water, which emerged from oceans, as a major component of living beings. The churning action of the ocean was thought very significant, and they visualized the oceans churned collaboratively by Gods (Devas - good aspects) and Demons (Asuras - bad aspects) with a mountain named Meruto produce a highly toxic scum that floated (lighter in nature - lipoidal?) capable of killing all life. Hence, they asked Lord Shiva to detoxify it. He drank it, but to prevent the poison from spreading into his body, wrapped a snake (not finding a rope) around his neck. The snake absorbed the poison and kept Lord Shiva (now known as Nilakantha- blue necked one) alive. This is the first record of a snake symbolized as a life saverit has been the insignia of the medical profession since.

\section{Concepts of Ayurveda}

The ancients visualized one universal and pure life force (Prana) present in all Molecules (Anu) and Atoms. (Parmanu). This energy is deemed to have male (Purusha) and female (Prakruti) attributes, also seen in Yin and Yang of Chinese concepts. High energy molecules are lighter where atoms are well separated as in Air (Vayu-Vata), those closer gave sense of cohesive solidity as in Earth (Snigdha- Kapha), and there is a component responsible for production of energy (Fire - Pitta). Such perception led to the fundamental concept of Tridosha, the three humors, namely Vata (V), Pitta (P) and Kapha (K). Their hierarchical manifestation provided five basic elements (PanchaMahabhutas = PM) namely Earth (Pruthvi), Water (Jala), Fire (Agni), Air (Vayu) and Space (Akash)- their relationships are shown in Figure 2.1. The PMare not discrete entities but have a continuum of Entropy and Enthalpy. As we move from Earth, Water, Fire, Air to Space we observe progressive randomness and spatial increments between molecules (horizontally) and Entropy or degree of vibrational energy vertically. This space concept between the molecules can also be viewed as internal repulsive forces. Sequential PM arrangement fits well with Van der Waal forces. Not only it is such a beautiful relationship evident in the five elements, in combination they give vibrational energy attributes to VPK.

Further they proposed that body has seven organs and tissues (Dhaus), namely Plasma (Rasa), blood (Rakta), Muscles (Mansa), Fat (Meda), Bones (Asthi), Bone marrow (Maja) and Reproductive 
tissues (Sukra for males and Artava for females). Understanding these fundamentals of the Ayurvedic concepts is crucial in determining the state of health (balance) or sickness (imbalance). Knowing each individual Dhatu and its property will help us to understand specific Arbud (cancer) and rationale in selecting appropriate treatments. Furthermore these VPK attributes are not only for human beings but also for plants, minerals and animals which are employed to prepare specific medication. We observe VPK in human growth. Children with cohesiveness have Kapha attributes and potential to grow. Younger people need higher energy (Pitta) for their body growth. Progressively more spacing and more randomness become attributes of aging Vata patients. Predominant ailments follow these patterns, namely Kapha diseases in children, Pitta problems in young -adults and Vata related ailments in older folks.

There are also temporal and temperature (energy) relationships with biological clock and circadian patterns. Cool Kapha in the morning (6-10AM) followed by warmer Pitta during mid-day (10AM-2PM) and heat and randomness in Vata phase (2-6PM). The body progressively needs more and more energy from the daybreak onwards, which are reflected in metabolic and physiological processes. The cycle continues and we are motionless during first phase of sleep, get active and ready to move in the morning. All these patterns have far reaching health and disease consequences. During the day it reaches the highest demand state around 4:00PM, when we become hypoglycemic, wasted and tired and demand a quick energy boost. Such profound observations are intrinsic and universal components of Ayurveda. Foods, medicinal plants, minerals and animal products all have varying balance and imbalance of VPK. For example those materials with high Vata properties will aggravate Vata. Patients with basic Vata constitutions should not consume such foods and diets.

\section{The disease}

Cancer by any name is an extremely complex disease with multiple facets. It may initiate at one site, proliferate and metastasize to other sites and just take over unpredictably. The complexity is at every level of anatomy, physiology, biochemistry, molecular biology, genetics etc. Science and medicine have made tremendous strides but the disease still evades us. In addition to loss of life, it has drained families, governments and health care agencies of resources. The sad part is that it has been with us as far back as we can recall.

\section{Cancer: western perspective}

Cancer is viewed as an abnormal neoplastic malignancy resulting from loss of normal regulatory biochemical and cellular control resulting in abnormal growth, lack of differentiation and ability to metastasize and invade other cells and tissues.

Though we have acquired considerable understanding of oncology, the precise mechanism is unclear. There is no specific requirement for cancer to strike. It is indiscriminate and universal and can invade individuals irrespective of age, sex, cultural and ethnic background, and geography. Though no specific etiology is involved, factors include genetic inheritance, oncogene expression, chromosomal breakage, viral, bacterial and parasitic infections, food-nutrition, chemical carcinogens, UV radiation, ionizing radiation etc. Almost always, the patient's immunity is compromised. There also seems to be an unregulated cell cycle (G0 -G1 -S-G2-M) in individual cells in different tissues and even in different sites in the same tissue. All these make it a forbidding task to successfully treat and cure cancers.

Today we have three formal and well-recognized treatments: Surgery, Radiotherapy and Chemotherapy.
If detected early and done competently, surgical procedures can have success rates as high as $94 \%$ in cervical cancers to as low as $37 \%$ for lung cancers Similarly radiotherapy can provide $88 \%$ success in Hodgkin's disease to only $9 \%$ for lungs. Chemotherapy (mostly interfering cell cycles) also exhibits wide range of success from $95 \%$ in Choriocarcinoma to only $16 \%$ for lungs. Lung cancer is the most difficult to treat and cure (see author's Immunomodulatory approach). As individual treatments often do not provide desired cure, combinations are practiced widely. There are other methods being investigated and include hyperthermia, neutron bombardment, interferon, chemicals like hydrazine sulfate and steroids. In addition many complementary and alternative medicines and approaches including Ayurvedic medicines are being investigated and are the topics of this book.

\section{Arbuda: ayurvedic views}

Arbuda: Though the most detailed description is in SushrutSamhita (1-11-388-392), the earliest use is found in Rig-Ved and AtharvVed. The most descriptive literary meaning is swelling like little mountain. There are over a dozen other descriptive synonyms that could be associated with one or more of characteristics of the ailment. In addition to specific organ-related Arbuda, there is always a varied amount of contribution from the seven Dhatus mentioned earlier. According to Ayurveda, no disease can manifest without some imbalance of the Tridoshas, Vata, Pitta and Kapha. For this article, 'Cancer' will be used for Allopathic and 'Arbuda' for Ayurvedic systems and they will be used interchangeably.

Arbuda is classified on various basis as follows:

a. Tridosha (Humors): Vataj, Pittaj, Kaphaj, Samprapti ( Pathogenesis), Sannipat (combination) Dwi(two) or Tri (three) Doshas

b. Dhatus (Tissues): Rakta (blood), Mansa (muscles), Meda (fat), Asthi (bones) etc.

c. Anga (Organs): Shira (Head), Mukha (mouth), Gala (Neckthroat), Yakrut (Liver) etc.

d. Progression: Sotha (Inflammatory swelling), Granthi (glandular swelling), Arbuda (Tumor), Drusta (malicious)/karkat (Cancer) malignant, Adhy/Rogasthanantar (Metastatic), Dwir (multiple/ progressed metastasis)

e. Curability: Susadhya (easily cured), KastAsadhya (difficult to cure), Asadhya (Impossible to cure)

There is no single model for Arbuda. Based on literature information, training, school of thought, etiopathology of the patient and the state of development and progression of the disease, each Vaidya generates a model. Ayurvedic models are essentially conceptual and have dynamic components. The Vaidya draws extensively from ancient texts, his or her formal training, personal experience and most importantly his patient and specifically how he views it. Though Ayurveda is universal in India, in the north it is less influenced by Siddha, the system of the south. The views of one southern Vaidya, Mahadevalyer, is particularly interesting as they are influenced by Siddha medicine. In general one can conceptualize and incorporate following aspects in Arbuda/Cancer model.

\section{Diagnosis}

Nidan (Diagnosis): Modern Ayurvedic practitioners incorporate salient features of Ancient and modern Western diagnostics. In 
particular, they use numerous criteria to determine Basic Constitution (Prakruti), which then becomes the basis for every aspect of treatment. For our discussion, the general diagnosis will be to determine Prakruti (Basic constitution), Balance/Imbalance of Tridoshas, Body (Sarira, Physical, somatic) , Physiology (Dharmguna), Psychological ( Mansik) and Spiritual (Adhyatmik). See Nidansection below. I have extensively used subjective and objective Radial Pulse examination (see below), questionnaires, pulse, patient's own evaluation, etc. I rely heavily on the reports of Oncologists, Blood work, X-rays, Physical Examination Reports and if necessary order specific analyses.

$$
\begin{gathered}
\text { Nidan (Diagnosis) } \\
\downarrow \\
\text { Pariksha (Examination, e.g. Nad } \\
\downarrow \\
\text { Prakruti/Vikruti/Tridosha (Balance/Imbalance details) } \\
\downarrow \\
\text { Vitiated Doshas } \\
\downarrow \\
\text { Distribution of Doshas in Dhatus } \\
\downarrow \\
\text { Body, Physiology, Psychology } \\
\downarrow \\
\text { Pariksha (Examination, e.g. Nadi) } \\
\downarrow \\
\text { Doshas and SubDoshas } \\
\downarrow \\
\text { Rogalakshan (Symptoms of disease) } \\
\downarrow \\
\text { Agni (Digestive fire, level of digestion, Ama considerations) } \\
\downarrow \\
\text { Srotas (Body Channels) } \\
\downarrow \\
\text { Prashna (Inqiries, details eg. Genetics, habits, diets, life style) } \\
\downarrow \\
\text { Nirnaya (decision) }
\end{gathered}
$$

(Conclusion/ final determination, manifestation and level of the disease, complications etc.)

Two major criteria are discussed here (a) NadiPariksha (Radial Pulse Examination), and (b) Determination of Basic constitution.

\section{Treatment-ayurvedic}

Ayurvedic treatments: They are holistic and take into account all the aspects of concepts, principles and practices discussed in section 2. Cancer treatments are no exception. Each Vaidya generates protocol depending on his/her specialty. Most every one determines the Tridosha balance/imbalance and obtains chronological history of the patient. I have generated my own Consultation- Diagnosis Protocol similar to many Vaidyas. During patient's first visit I conduct Nadi Pariksha/Radial Pulse Examination between 8-9AM, to be consistent with biological clock requirements. The patient provides his/her evaluation by filling forms. A detailed evaluation proceeds, all the information is scrutinized and if necessary additional information is requested. Patient gets detailed instructions on medication, dietary preferences and constraints, if necessary changes in daily routines, instructions on meditation and exercise for mind-body connections. The entire approach is holistic and every aspect of life if focused for Self-healing and bringing in harmony to imbalances. Emphasis is made that, 'No compliance No Cure'. Patient is given option to participate in PMAA (Personalized Medicine according to Atharva Ayurveda) Strict warning is given for 'Safety First' and patient should stop all medications if any unusual symptoms occur.

\section{Future: concepts, rationale and strategies}

In the search of novel approaches to combat cancer I have compared several modalities employed by both Western and Eastern medical disciplines. I have addressed following questions:

I. Understand Ayurvedic views on initiation and progression of Arbuda (Cancer)

II. Develop non-invasive diagnostic technology

III. Discover agents that will correct the melody (palliative) and cure the disease

IV. Future strategy to combat and cure Cancer(PMAA)

\section{Ayurvedic views}

The first overt symptom in the pathogenesis (Samprapti) of Arbuda is swelling (Sotha). Sotha according to Ayurveda may result from many causes. They most contributory factor is Ama, which results from incomplete digestion (Apakva) of foods due to lack of biofire (MandAgni). Ama is considered to be acidic toxin. It is produced in stomach and if not properly neutralized reducing food intake, namely fasting (Langhan), eating less and only what gets easily digested and/ or increasing Agni. If unattended it slowly and progressively disperses from digestive system to other tissues. This acidic - low $\mathrm{pH}$ - toxin may subtly alter many cellular processes, including many enzymatic reactions, homeostasis, cellular transport etc. Acidity sets in and cells become less resilient and forms hard swollen masses (Granthi). Depending on many factors including genetic make up of the person, foods, diets, smoking and in take of many carcinogens, the Granthi now grows to an enlarged Arbuda, the Tumor. I have implicated two very important cellular components, namely microtubules (Nadis) and microfilaments (Srotas). They are impaired. They are normally involved in maintaining cellular structural coherence and turgidity through septate desmosomes and tight junctions. What seems to result is that cell becomes abnormal and loses its inherent communication functions. Normal microfilamental astral bodies fail to regulate cell division, which results in abnormal growth. State of malignancy (Drusta orKarkat) sets in and it spreads subsequently to other cells and tissues (Dhatus). This result in metastasis (Dwir). This type of logical thinking, right or not, implicates microtubules (Nadi) and microfilaments (Srotas). Sushrut attributes formation of Arbuda to them. It became apparent that I must measure either structural integrity or functional capacity of Nadi and Srotas. This should preferably done directly on the patient and also the diagnosis must be non-invasive.

\section{Acknowledgments}

None.

\section{Conflicts of interest}

Author declares there are no conflicts of interest. 